\title{
Pengaruh Hidrolisat Kolagen dari Kulit Ikan Patin (Pangasius pangasius) terhadap Umur Simpan Pempek Ikan Gabus (Channa striata)
}

\section{Effect of Skin Collagen Hydrolyzate of Catfish (Pangasius pangasius) to the Shelf Life of Pempek from Snakehead (Channa striata)}

\author{
Ace Baehaki1a, Rodiana Nopianti1 ${ }^{1}$ Linda Transtio Wati1
}

Program Studi Teknologi Hasil Perikanan, Fakultas Pertanian Universitas Sriwijaya ; Indralaya Ogan Ilir Sumatera Selatan

aKorespondensi: Ace Baehaki, E - mail : ace76_none@yahoo.com

(Diterima oleh Dewan Redaksi : 09 - 10 - 2018)

(Dipublikasikan oleh Dewan Redaksi : 30 - 04 - 2019)

\begin{abstract}
The objective of this research was to observe the ability of collagen hydrolyzate as an antioxidant in the product of pempek. The factors of treatment consisted of collagen hydrolyzate concentration which was added and the storage time $(0,1,2,3$ and 4 days $)$. The parameters observed were chemical analysis (water content, protein content, fat content and free fatty acid), microbiological analysis (Total Plate Count) and organoleptic test (appearance, color, odor, and texture). The addition of 1\% collagen hydrolyzate on pempek during 4 days of storage at room temperature gave the best treatment by maintaining water content $66 \%$, fat $0.81 \%$ and organoleptic testing with the hedonic quality test on appearance, color, aroma and texture. The results of the characteristics of collagen hydrolyzate analysis showed that the use of hydrolyzate concentration in the product of pempek was not able to inhibit the oxidation process that caused rancidity in foods.
\end{abstract}

Keywords : skin collagen hydrolysate, pempek, free fatty acids

\begin{abstract}
ABSTRAK
Penelitian ini bertujuan untuk mengetahui aplikasi hidrolisat kolagen sebagai antioksidan pada produk pempek. Faktor perlakuan terdiri dari konsentrasi hidrolisat kolagen yang ditambahkan dan lama penyimpanan (tanpa penyimpanan, 1, 2, 3 dan 4 hari). Parameter yang diamati meliputi analisis kimia (kadar air, kadar protein, kadar lemak dan asam lemak bebas), analisis mikrobiologi (Total Plate Count) dan uji organoleptik mutu hedonik (kenampakan, warna, bau dan tekstur). Penambahan hidrolisat kolagen $1 \%$ pada pempek selama penyimpanan 4 hari pada suhu ruang memberikan perlakuan terbaik dengan mempertahankan kadar air $66 \%$, lemak 0,81\% dan pengujian organoleptik dengan uji mutu hedonik pada kenampakan, warna, aroma dan tekstur. Hasil analisis karakteristik hidrolisat kolagen menunjukkan bahwa penggunaan konsentrasi hidrolisat dalam produk pempek belum mampu menghambat proses oksidasi yang menyebabkan ketengikan pada bahan pangan. Hidrolisat kolagen yang ditambahkan pada pempek ikan gabus berfungsi sebagai pangan fungsional.
\end{abstract}

Kata Kunci: hidrolisat kolagen kulit, pempek, asam lemak bebas

Baehaki, ace, Rodiana Nopianti, Linda Transtio Wati. Pengaruh hirolisat kolagen dari kulit ikan patin (Pangasius pangasius) terhadap umur simpan pempek ikan gabus (Channa striata) .Jurnal Agroindustri Halal 5(1): 067-074 


\section{PENDAHULUAN}

Pempek adalah produk olahan ikan berbentuk gel dengan tekstur yang kenyal dan elastis, sama halnya seperti kamaboko di Jepang. Jenis ikan yang banyak digunakan sebagai bahan baku pempek adalah ikan gabus. Ikan gabus (Channa striata) merupakan salah satu ikan perairan tawar yang memiliki protein yang tinggi, daging yang putih, dengan tekstur yang lebih kenyal. Hal ini menjadikan ikan gabus bernilai ekonomi tinggi (Agustini, 1996).

Pempek yang disimpan pada suhu ruang biasanya hanya bertahan tidak lebih dari dua hari, selebihnya pempek berbau tengik dan rasanya tidak enak. Salah satu cara untuk mengurangi bau tengik pada pempek yaitu dengan penambahan antioksidan untuk menghambat timbulnya ketengikan yang disebabkan reaksi oksidasi.

Hidrolisat kolagen adalah kolagen yang telah mengalami proses hidrolisis polipeptida. Hidrolisat kolagen dihasilkan dari proses hidrolisis kolagen yang terdapat pada tulang, kulit dan jaringan ikat hewan seperti sapi, ikan, kuda, babi dan kelinci. Pada proses hidrolisis polipeptidapolipeptida kolagen akan dipecah menjadi molekul yang lebih sederhana ada yang menggunakan larutan asam atau alkali dan enzim (Swidersky, 2009).

Berdasarkan penelitian Baehaki al al. (2015) menyatakan bahwa hidrolisat kolagen dari kulit dan tulang ikan patin (Pangasius pangasius) dengan enzim papain diketahui memiliki aktivitas antioksidan. Oleh karena itu perlu dilakukan pengaplikasian dalam bahan pangan untuk mengetahui kelayakan hidrolisat kolagen dan peluang bahan tersebut sebagai alternatif antioksidan pangan.

\section{MATERI DAN METODE}

\section{Bahan dan Alat}

Alat yang digunakan meliputi autoklaf, inkubator, desikator, inkubator, alat titrasi, pemanas listrik (hot plate), tabung reaksi, dan coloni counter.

Bahan baku yang digunakan adalah ikan gabus (Channa striata), hidrolisat kolagen dari kulit ikan patin, tapioka dan garam. Analisis yang dilakukan menggunakan bahan $\mathrm{K}_{2} \mathrm{SO}_{4}, \mathrm{HgO}$, selnium, $\mathrm{H}_{2} \mathrm{SO}_{4}$ pekat, $\mathrm{NaOH}, \mathrm{H}_{3} \mathrm{BO}_{3}, \mathrm{HCl}$, larutan $\mathrm{BaCl} 2$, pelaarut dietil eter, alkohol 95\%, indikator fenolftalein, larutan butterfields phospate buffered, larutan PCA (Plate Count Agar).

\section{Metode Penelitian}

Pada penelitian ini hidrolisat kolagen yang digunakan adalah hidrolisat kolagen kulit ikan patin dengan penambahan enzim papain 5\% selama 160 menit (Angraini, 2014). Penelitian ini menggunakan dua faktor perlakuan yang terdiri dari konsentrasi hidrolisat kulit yang ditambahkan pada pempek (A) dan lama penyimpanan pempek pada suhu ruang (T). Setiap perlakuan yang ada dilakukan pengulangan sebanyak dua kali. Perlakuan yang digunakan pada perlakuan ini adalah sebagai berikut :

\section{a. Faktor I \\ A0 $=$ Kontrol (tanpa penambahan) \\ $\mathrm{A} 1$ = Penambahan hidrolisat kolagen $1 \%$ \\ A2 = Penambahan hidrolisat kolagen 2\% \\ A3 = Penambahan hidrolisat kolagen 3\% \\ b. Faktor II \\ T0 = Tanpa Penyimpanan \\ $\mathrm{T} 1$ = Penyimpanan hari ke-1 \\ $\mathrm{T} 2$ = Penyimpanan hari ke-2 \\ $\mathrm{T} 3$ = Penyimpanan hari ke-3 \\ $\mathrm{T} 4$ = Penyimpanan hari ke-4}

\section{Pembuatan Pempek (Agustini, 1996) yang dimodifikasi.}

Dalam pembuatan pempek ini, perbandingan daging ikan dan tepung tapioka yang digunakan adalah 1:1. Daging ikan gabus giling dicampurkan dengan air sebanyak 20\% dari berat bahan. Kemudian tambahkan garam sebanyak 2\% dari berat 
bahan dalam adonan. Hidrolisat yang digunakan 5\% dari perlakuan terbaik (Angraini, 2014). Kemudian hidrolisat kolagen ditambahkan $0 \%, 1 \%, 2 \%$ dan 3\% untuk setiap perlakuan lalu diaduk sampai tercampur rata. Masukkan sedikit demi sedikit tepung tapioka ke dalam adonan sampai tercampur rata. Adonan dibentuk lenjeran dengan panjang sekitar $10 \mathrm{~cm}$ dengan diameter $3 \mathrm{~cm}$. Kemudian pempek direbus dalam air mendidih selama 20 menit kemudian diangkat dan ditiriskan.

Parameter yang diamati meliputi uji kimia yang meliputi: kadar air, kadar lemak, kadar protein, asam lemak bebas, uji mikrobiologi (TPC) dan uji sensoris yang meliputi: penampakan, warna, aroma dan tekstur.

\section{HASIL DAN PEMBAHASAN}

\section{Analisis Kimia}

\section{Kadar Air}

Kadar air pempek dengan penambahan hidrolisat kolagen kulit ikan patin dapat dilihat pada Gambar 1. Gambar 1 menunjukkan pengaruh konsentrasi hidrolisat kolagen dan lama penyimpanan terhadap kadar air pempek yang dihasilkan.

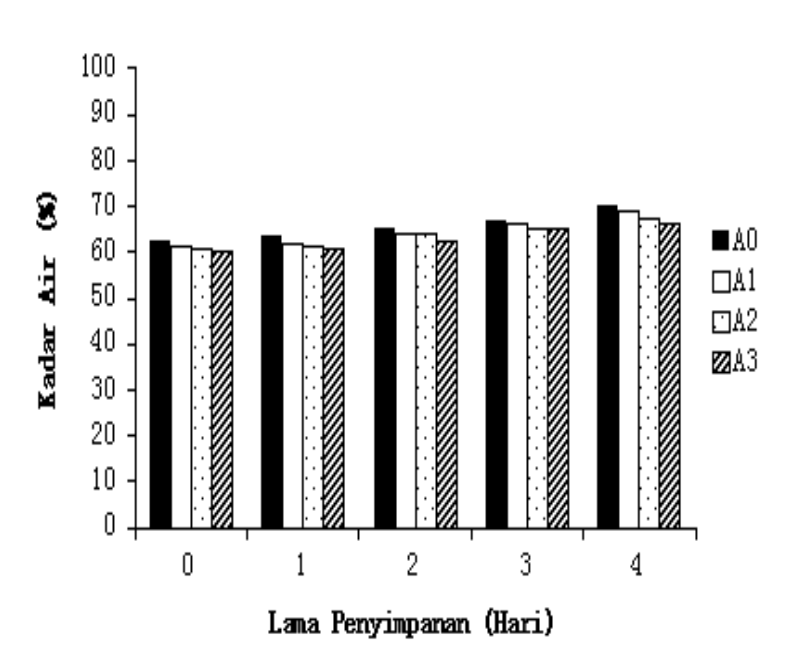

Gambar 1. Kadar air (\%) pempek selama penyimpanan $(\mathrm{A} 0=$ tanpa penambahan hidrolisat, $\mathrm{A} 1=$ penambahan hidrolisat $1 \%$, $\mathrm{A} 2=$ penambahan hidrolisat $2 \%$ dan A3=penambahan hidrolisat 3\%)
Semakin lama penyimpanan pempek pada suhu ruang semakin tinggi kadar air pempek. Hal ini disebabkan selama penyimpanan, pempek menyerap air dari lingkungannya.

Nilai kadar air pempek dengan perlakuan penambahan hidrolisat kolagen mengalami penurunan dibandingkan dengan pempek kontrol. Hal ini disebabkan jumlah air yang ditambahkan pada proses pembuatan semakin berkurang yang diganti dengan hidrolisat kolagen.

\section{Kadar Lemak}

Rerata kadar lemak pempek hidrolisat kolagen kulit ikan patin dapat dilihat pada Gambar 2.

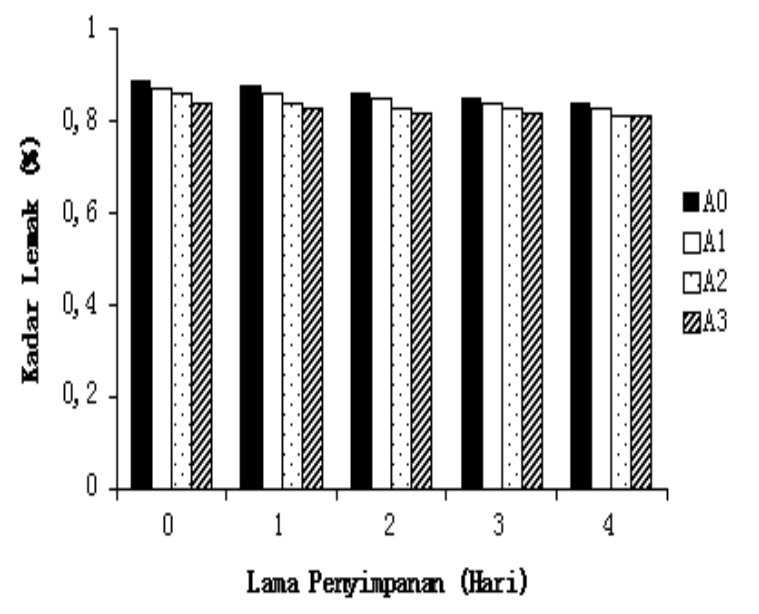

Gambar 2. kadar lemak (\%) selama penyimpanan $(\mathrm{A} 0=$ tanpa penambahan hidrolisat, $\mathrm{A} 1=$ penambahan hidrolisat $1 \%$, $\mathrm{A} 2=$ penambahan hidrolisat $2 \%$ dan A3=penambahan hidrolisat 3\%)

Gambar 2 menunjukkan pengaruh konsentrasi hidrolisat kolagen kulit ikan patin dan lama penyimpanan terhadap kadar lemak pempek pada suhu ruang. Semakin lama penyimpanan, pempek mengalami sedikit penurunan kadar lemak. Konsentrasi hidrolisat kolagen yang ditambahkan juga menyebabkan terjadinya penurunan kadar lemak. Penurunan kadar lemak ini disebabkan karena proses oksidasi pada pempek. Kerusakan lemak yang utama adalah timbulnya bau tengik yang disebut proses 
ketengikan. Adanya hidrolisat kolagen belum mampu memperlambat kerusakan lemak akibat oksidasi lemak.

\section{Kadar Protein}

Rerata kadar protein pempek hidrolisat kolagen kulit ikan patin dapat dilihat pada Gambar 3.

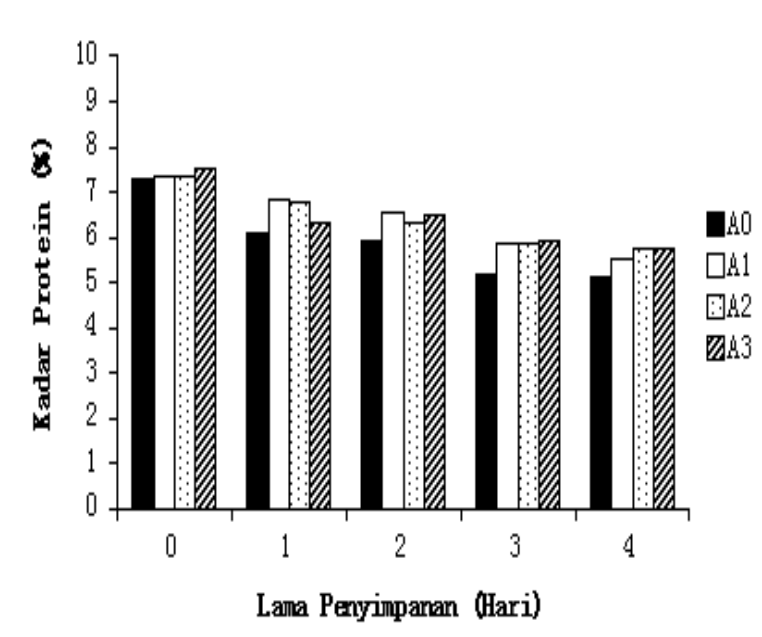

Gambar 3. Kadar protein selama penyimpanan $(\mathrm{A} 0=$ tanpa penambahan hidrolisat, $\mathrm{A} 1=$ penambahan hidrolisat $1 \%$, $\mathrm{A} 2=$ penambahan hidrolisat $2 \%$ dan A3=penambahan hidrolisat 3\%).

Gambar 3 menunjukkan pengaruh penambahan hidrolisat kolagen dan lama penyimpanan terhadap kadar pempek yang dihasilkan. Lama penyimpan pada suhu ruang menunjukkan terjadinya penurunan kadar protein pempek. Penurunan kadar protein ini akibat terjadinya proses proteolitik, yang semakin lama aktivitas proteolitiknya semakin tinggi sehingga kadar protein menurun.

Penambahan hidrolisat kolagen cenderung meningkatkan kadar protein pempek hal ini mungkin disebabkan aktivitas inhibitor proteolitik pada hidrolisat kolagen sehingga akitvitas proteolitik berkurang sehingga kadar proteinnya cenderung meningkat.

\section{Asam lemak Bebas}

Rerata asam lemak bebas pempek hidrolisat kolagen kulit ikan patin dapat dilihat pada Gambar 4.

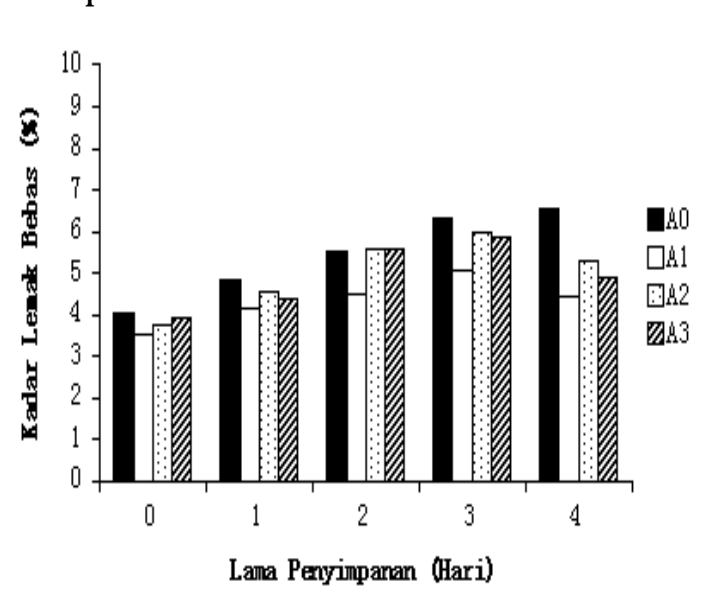

Gambar 4. Kadar asam lemak bebas selama penyimpanan $(\mathrm{A} 0=$ tanpa penambahan hidrolisat, $\mathrm{A} 1=$ penambahan hidrolisat $1 \%$, $\mathrm{A} 2=$ penambahan hidrolisat $2 \%$ dan A3=penambahan hidrolisat 3\%)

Hasil penelitian menunjukkan bahwa pempek dengan perlakuan penambahan hidrolisat kolagen memiliki nilai yang sedikit rendah dibandingkan dengan pempek tanpa hidrolisat kolagen. Kadar lemak bebas yang rendah dengan penambahan hidrolisat kolagen menunjukkan adanya aktivitas antioksidan pada hidrolisat kolagen. Aktivitas antioksidan yang ada dalam hidrolisat kolagen mampu melindungi lemak dari proses oksidasi. Hidrolisat kolagen dari kulit dan tulang ikan memilki aktivitas antikosidan (Baehaki et al., 2016; Lin et al., 2010)).

\section{Analisis Mikrobiologi (TPC)}

Total mikroba perlu diketahui untuk memastikan suatu bahan pangan layak untuk dikonsumsi. Pertumbuhan mikroba dalam bahan pangan erat hubungannya dengan jumlah kandungan air. Rerata TPC (Total Plate Count) pempek hidrolisat kolagen kulit ikan patin dapat dilihat pada Tabel 1. 
Tabel 1. nilai TPC selama penyimpanan

\begin{tabular}{|c|c|c|c|c|}
\hline \multirow{2}{*}{$\begin{array}{c}\text { Penyim } \\
\text { panan }\end{array}$} & $\begin{array}{c}\text { Kontrol } \\
\text { (A0) }\end{array}$ & $\begin{array}{c}\text { Hidrolisat } \\
\text { kolagen } \\
1 \%(\mathrm{~A} 1)\end{array}$ & $\begin{array}{c}\text { Hidrolisat } \\
\text { kolagen } \\
2 \%(\mathrm{~A} 2)\end{array}$ & $\begin{array}{c}\text { Hidrolisat } \\
\text { kolagen } \\
3 \%(\mathrm{~A} 3)\end{array}$ \\
\cline { 2 - 5 } 0 hari & $1,45 \times 10^{2}$ & $1,40 \times 10^{2}$ & $2,35 \times 10^{2}$ & $2,70 \times 10^{2}$ \\
\hline 1 hari & $4,75 \times 10^{3}$ & $4,55 \times 10^{3}$ & $7,20 \times 10^{2}$ & $2,15 \times 10^{2}$ \\
\hline 2 hari & $8,10 \times 10^{5}$ & $3,50 \times 10^{4}$ & $4,70 \times 10^{3}$ & $3,25 \times 10^{3}$ \\
\hline 3 hari & $4,95 \times 10^{5}$ & $5,75 \times 10^{4}$ & $5,95 \times 10^{4}$ & $3,20 \times 10^{4}$ \\
\hline 4 hari & $2,75 \times 10^{6}$ & $3,15 \times 10^{6}$ & $6,05 \times 10^{6}$ & $4,95 \times 10^{6}$ \\
\hline
\end{tabular}

Hasil pengujian mikrobiologi (Total plate count) pada Tabel 1 diketahui bahwa dari masing-masing perlakuan, jumlah mikrooganisme cenderung semakin meningkat dengan lamanya penyimpanan. Namun, selama penyimpanan pempek yang tanpa perlakuan hidrolisat kolagen memiliki nilai TPC yang lebih tinggi dibandingkan dengan nilai TPC pempek yang diberi perlakuan hidrolisat kolagen $1 \%, 2 \%$ dan 3\%, baik pada penyimpanan hari ke- 0 , ke-1, ke-2, ke-3 dan ke-4.

Penyimpanan pada hari ke- 0 nilai TPC untuk tanpa perlakuan dan menggunakan perlakuan tidak jauh berbeda, namun pada hari berikutnya nilai TPC pada pempek kontrol jumlahnya meningkat dengan cepat dibanding dengan menggunakan perlakuan hidrolisat kolagenn sampai hari ke-3. Dimana nilai total mikroba hidrolisat kolagen 0\% pada hari pertama adalah $1,45 \times 10^{2} \mathrm{cfu} / \mathrm{g}$ dan meningkat di hari ke-2 menjadi 4,75 $\mathrm{x}$ $10^{3} \mathrm{cfu} / \mathrm{g}$. Penggunaan hidrolisat kolagen yang mampu menuunkan nilai TPC disebabkan adanya aktivitas antimikroba pada hidrolisat kolegan. Menurut Swidersky (2009), peptida kolagen dapat berpotensi sebagai antimikoba, antihipertensi, immunomodulator dan antioksidan.

\section{Analisis Sensori}

\section{Kenampakan}

Hasil pengujian organoleptik dari kenampakan pempek dapat dilihat pada Gambar 5.

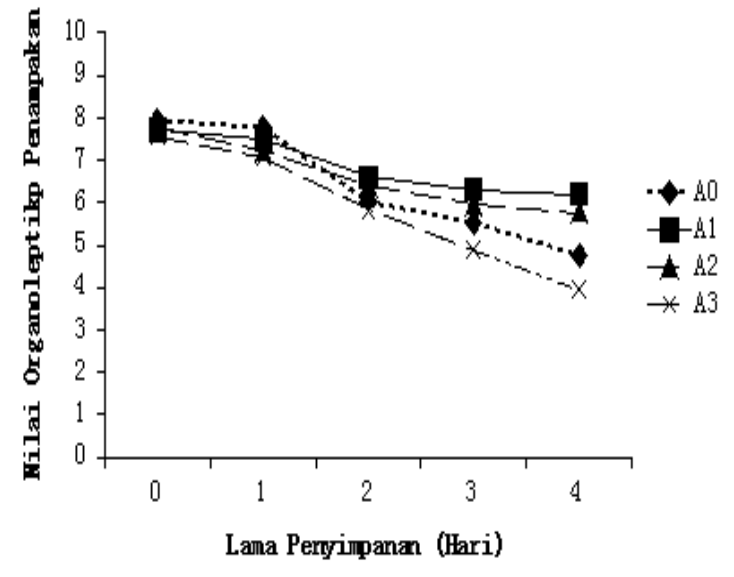

Gambar 5. Nilai penampakan pempek selama penyimpanan $(\mathrm{A} 0=$ tanpa penambahan hidrolisat, $\mathrm{A} 1=$ penambahan hidrolisat $1 \%$, $\mathrm{A} 2=$ penambahan hidrolisat $2 \%$ dan A3=penambahan hidrolisat 3\%)

Gambar 5 menunjukkan bahwa perlakuan pempek dengan penambahan hidrolisat kolagen mengalami penurunan selama penyimpanan. Perlakuan A3 (pempek dengan hidrolisat kolagen 3\%) mengalami penurunan dibandingkan perlakuan A0 (pempek tanpa hidrolisat kolagen). Penurunan nilai penampakan selama penyimpanan diduga karena kandungan air produk selama penyimpanan (Chamidah dan Kartikaningsih, 2000).

\section{Warna}

Warna berperan sebagai perinci jenis, tanda-tanda kerusakan, petunjuk tingkat mutu dan pedoman proses pengolahan pada produk pangan (Soekarto, 1985 dalam Wiraswanti, 2008). Hasil uji mutu hedonik untuk parameter warna dapat dilihat pada Gambar 6. 


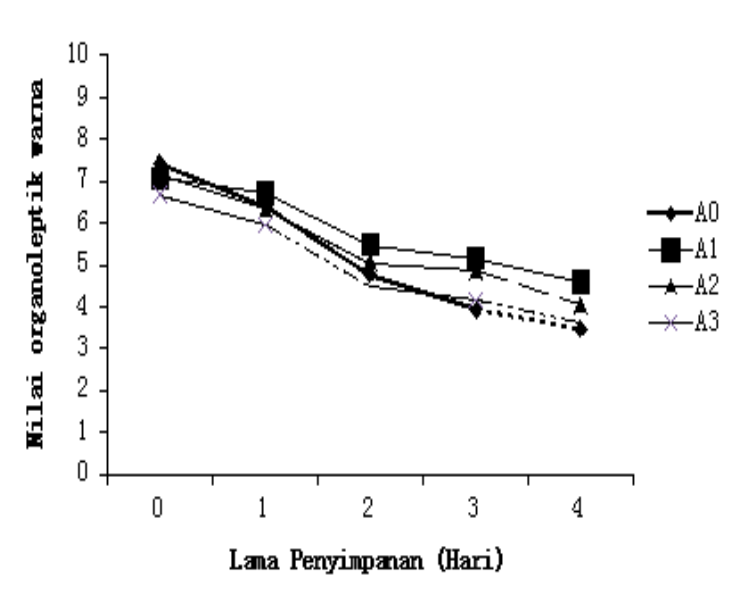

Gambar 6. Nilai warna pempek selama penyimpanan $(\mathrm{A} 0=$ tanpa penambahan hidrolisat, $\mathrm{A} 1=$ penambahan hidrolisat $1 \%$, $\mathrm{A} 2=$ penambahan hidrolisat $2 \%$ dan A3=penambahan hidrolisat 3\%).

Berdasarkan Gambar 6. menunjukkan warna pempek ikan gabus mengalami penurunan selama penyimpanan. Hasil rerata nilai warna pempek yang dilakukan panelis memiliki kisaran nilai $3,48-7,4$ (pempek tanpa hidrolisat kolagen), 4,6-7,08 (pempek dengan hidrolisat kolagen 1\%), 4,04-7,16 (pempek dengan hidrolisat kolagen 2\%) dan 3,64-6,68 (pempek dengan hidrolisat kolagen 3\%). Penilaian panelis memberikan nilai yang terbaik pada hidrolisat kolagen 1\% yang ditambahkan pada pempek. Hal ini menunjukkan bahwa warna pempek dengan penambahan hidrolisat kolage 1\% paling disukai panelis dibandingkan penambahan perlakuan lainnya. Perubahan warna yang terjadi pada produk selama penyimpanan disebabkan oleh perubahan mutu yang disebabkan oleh aktivitas mikroba di dalam produk. Aktivitas mikroba ini memiliki enim yang dapat memecahkomponen-komponen bahan pangan menjadi senyawa sederhana yang mengakibatkan perubahan-perubahan sifat makanan seperti warna, bau, rasa dan tekstur (Fardiaz, 1989).

\section{Aroma}

Aroma merupakan salah satu faktor pendukung cita rasa yang menentukan kualitas suatu produk. Aroma juga merupakan salah satu indikator untuk menentukan tingkat penerimaan suatu produk oleh konsumen. Penilaian panelis terhadap aroma dapat dilihat pada Gambar 7.

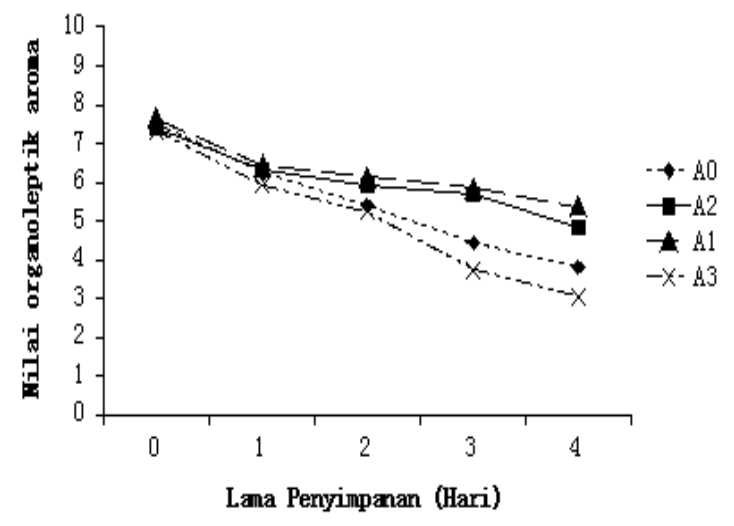

Gambar 7. Nilai aroma pempek selama penyimpanan $(\mathrm{A} 0=$ tanpa penambahan hidrolisat, $\mathrm{A} 1=$ penambahan hidrolisat $1 \%$, $\mathrm{A} 2=$ penambahan hidrolisat $2 \%$ dan A3=penambahan hidrolisat 3\%)

Gambar 7 menunjukkan bahwa aroma pempek selama penyimpanan mengalami penurunan. Hasil nilai aroma yang dilakukan panelis memiliki kisaran nilai 3,8-7,52 (pempek tanpa hidrolisat kolagen), 5,36 7,54 (pempek dengan hidrolisat kolagen 1\%), 4,84 - 7,4 (pempek dengan hidrolisat kolagen 2\%) dan 3,04 - 7,32 (pempek dengan hidrolisat kolagen 3\%). Menurut de Mann (1989), pengujian aroma dianggap penting karena produk terkait diterima atau tidaknya suatu produk ditentukan dari nilai aroma produk tersebut. Penurunan nilai warna setiap harinya disebabkan oleh terdenaturasinya protein selama penyimpanan sehingga menimbulkan bau busuk paad produk pempek yang menyebabkan panelis tidak menyukai pempek pada penyimpanan hari ke-4.

\section{Tekstur}

Faktor penting dalam pembuatan produk olahan daging adalah pada kemampuan saling mengikat antara partikel daging dengan bahan lain yang ditambahkan dan tekstur yang terbentuk (Purnomo, 1998). Rerata uji mutu hedonik terhadap 
tekstur pempek hidrolisat kolagen dapat dilihat pada Gambar 8.

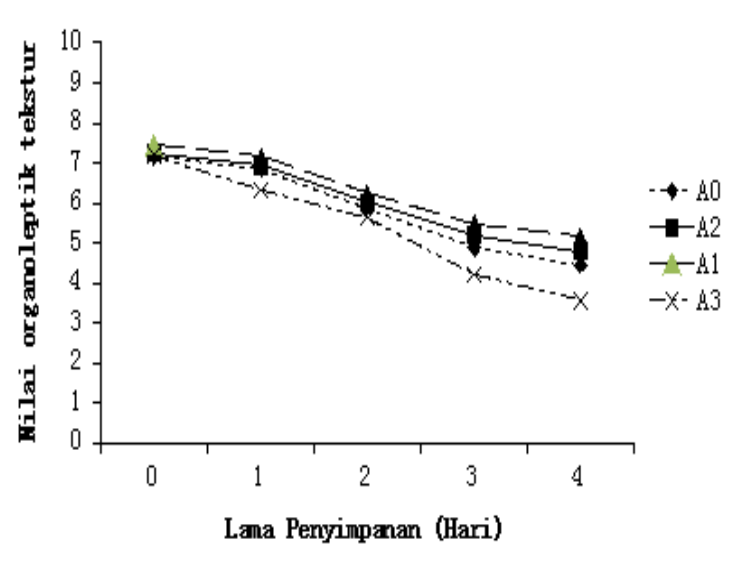

Gambar 8. Nilai tekstur pempek selama penyimpanan $(\mathrm{A} 0=$ tanpa penambahan hidrolisat, $\mathrm{A} 1=$ penambahan hidrolisat $1 \%$, $\mathrm{A} 2=$ penambahan hidrolisat $2 \%$ dan A3=penambahan hidrolisat 3\%)

Berdasarkan Gambar 7 menunjukkan tekstur pempek selama penyimpanan mengalami penurunan. Tekstur juga merupakan salah satu parameter yang penting dalam mempengaruhi pilihan konsumen terhadap produk. Hasil nilai tekstur pempek yang dilakukan panelis memiliki kisaran nilai 4,44- 6,84 (pempek tanpa hidrolisat kolagen), 5,64 - 7,14 (pempek dengan hidrolisat kolagen 1\%), 4,8 - 7,24 (pempek dengan hidrolisat kolagen 2\%) dan 3,56 - 7,2 (pempek dengan hidrolisat kolagen 3\%). Penurunan tekstur selama penyimpanan disebabkan oleh aktivitas dari mikroba yang bekerja mendegradasi protein pada pempek. Babji dan Kee (1994) menyatakan bahwa tekstur daging olahan ditentukan oleh kandungan protein miofibril dengan bahan-bahan pembantu seperti pati (bahan pengisi) dan garam.

\section{KESIMPULAN}

Perlakuan penambahan hidrolisat kolagen yang berbeda pada pempek tidak berpengaruh nyata terhadap analisis kimia (lemak) dan analisis mikrobiologi (TPC). Perlakuan penambahan hidrolisat kolagen yang berbeda pada pempek terbukti berbeda nyata terhadap analisis kimia (kadar air, protein dan asam lemak bebas). Hasil penelitian menunjukkan nilai rerata kadar air berkisar antara 60,3\% hingga $68,7 \%$, kadar protein 5,9\% hingga 7,52\%, kadar lemak 0,81\% hingga 0,89\% dan asam lemak bebas 3,5\% hingga 6,56\%. Nilai TPC berkisar antara 1,40\% hingga 8,10\%. Perlakuan terbaik yaitu penambahan hidrolisat kolagen 3\% sampai penyimpanan hari ke-3. Penambahan hidrolisat kolagen terbukti berbeda nyata terhadap kenampakan, warna, aroma dan tekstur pempek ikan gabus selama penyimpanan.

\section{DAFTAR PUSTAKA}

Angraini S. 2014. Pembuatan Hidrolisat Kolagen Kulit dan Tulang Ikan Patin (Pangasius pangasius) Dengan Enzim Papain dan Pengujian Aktivitas Antioksidannya [Skripsi]. Indralaya: Fakultas Pertanian, Universitas Sriwijaya.

Agustini L. 1996. Standarisasi Formula Empek-empek Palembang dari Ikan Gabus (Ophiocephalus striatus Blkr) [Skripsi]. Bogor: Jurusan Teknologi Pangan dan Gizi, Fakultas Teknologi Pertanian, Institut Pertanian Bogor.

Baehaki A, Nopianti R \& Anggraeni S. 2015. Antioxidant activity of skin and bone collagen hydrolyzed from striped catfish (Pangasius pangasius) with papain enzyme. Journal of Chemical and Pharmaceutical Research, 7(11): 131-135.

Baehaki A, Suhartono MT, Sukarno, Syah D, \& Setyahadi S. Antioxidant Activity of Collagen Hydrolysates from Fish Skin with a Microbial Collagenase. Research Journal of Pharmaceutical, Biological and Chemical Sciences, 7(2): 1677-1682.

Babji AS dan Kee GS. 1994. Changes in colour, pH, WHC, Protein Extraction and Gel Strength during processing of chicken surimi. Asean Food Journal: 63-68

deMan, J.M. 1989. Kimia makanan. Bandung: Institut Teknologi Bandung Press. 
Chamidah AY dan Kartikaningsih. 2000. Pengembangan Makanan Fermentasi Indonesia Bekasam Ikan Mujair, Tinjauan Aspek Mikrobiologi dan Kimia. Skripsi. Fakultas Pertanian Unversitas Brawijaya.

Fardiaz D. 1989. Hidrokoloid. Laboratorium Kimia dan Biokimia, Pusat Antar Universitas Pangan dan Gizi. Institut Pertanian Bogor.

Lin YJ, Le GW, Wang JY, Li YX, Shi YH \& Sun J. 2010. Antioxdative Peptides Derived from Enzyme Hydrolysis of Bone Collagen After Microwave Associated Acid Pre Treatment and Nitrogen Protection. International Journal of Molecular Science, 11:42974308.

Purnomo H. 1995. Aktivitas Air dan Peranannya dalam Pengawetan Pangan. Jakarta: UI Press.

Swidersky F. 2009. Hydrolizat collagen as suplement Diety. Journal of Applied Physics 16 : 123-128.

Wiraswanti I. 2008. Pemanfaatan Karagenan Dan Kitosan Dalam Pembuatan Bakso Ikan Kurisi (Nemipterus nematophorus) Pada penyimpanan Suhu Dingin dan Beku [skripsi]. Bogor: Institut Pertanian Bogor 